Research article

\title{
PREVALENCE, ANTIMICROBIAL RESISTANCE, AND MOLECULAR TYPING OF THERMOPHILIC CAMPYLOBACTER SPP. IN A GREEK POULTRY SLAUGHTERHOUSE
}

\author{
SAKARIDIS Ioannis ${ }^{1,2, *}$, PAPADOPOULOS Theofilos ${ }^{1,3}$, BOUKOUVALA Evridiki ${ }^{1}$, \\ EKATERINIADOU Loukia ${ }^{1}$, SAMOURIS Georgios ${ }^{1}$, ZDRAGAS Antonios ${ }^{1}$ \\ ${ }^{1}$ Veterinary Research Institute, Hellenic Agricultural Organisation-Demeter, Thessaloniki, Greece; \\ ${ }^{2}$ School of Veterinary Medicine, University of Surrey, Guildford, UK; \\ ${ }^{3}$ Department of Epidemiology and Public Health, Sciensano, Brussels, Belgium
}

(Received 01 April, Accepted 19 August 2019)

Campylobacter species are one of the leading causes of foodborne disease. Poultry is a major reservoir and source of its transmission to humans. The aim of this study was to estimate the prevalence and antimicrobial resistance of Campylobacter spp. isolated from chicken carcasses, the environment, and processing equipment of a poultry slaughterhouse in Greece, to identify the dominant Campylobacter species and to determine if there are clonal relationships among the isolates. Fifty poultry samples and 25 environmental samples were examined using microbial cultures and PCR. Fortynine of 50 poultry samples $(98 \%)$ were found to be positive for Campylobacter spp. The environment of the slaughterhouse was also found to be significantly contaminated with Campylobacterspp. Thirty-seven isolates were found to be susceptible to all antimicrobials tested $(56.1 \%)$ and 29 isolates showed resistance to at least two of the antimicrobials tested (43.9\%). We observed 24 different PFGE-types among the 53 isolates with 14 of them isolated only once, while five PFGE-types were represented by two isolates. The remaining 29 isolates were represented by five PFGE-types each consisting of three to 12 isolates. Regarding the relationship of the PFGE types and corresponding resistance profiles, all strains of each PFGE-type shared the same antimicrobial resistance profile. This study reports evidence for Campylobacter spp. cross-contamination among broiler carcasses in a Greek slaughterhouse.

Key words: Campylobacter, chicken, slaughterhouse, prevalence, antimicrobial resistance, molecular typing

\section{INTRODUCTION}

The presence of Campylobacter species on chicken carcasses is an important risk factor for human food-borne campylobacteriosis. According to the last published report of

\footnotetext{
*Corresponding author: e-mail: ioannis_s_@hotmail.com
} 
the European Food Safety Authority [1] campylobacteriosis is the most frequently reported zoonotic disease in humans in the European Union. The disease in humans caused by Campylobacter spp. is usually self - limited, mild symptoms are seen and is only lasting a few days [2]. However, in rare cases the appearance of non-gastrointestinal related complications may occur such as arthritis, neurological disorders and even the appearance of Guillain-Barré syndrome, a form of paralysis, which can lead to respiratory failure and severe neurological dysfunction, and even death [3]. Therefore, reducing the prevalence of Campylobacter spp. on chicken carcasses and the prevention of cross contamination with other food products is essential for the protection of public health.

Following the introduction of Campylobacter into a poultry farm, there is rapid transmission within the flock, which may be exacerbated by factors including stocking density and litter conditions [4,5]. Up to $100 \%$ of individual birds in a flock may be colonized by Campylobacter, with the highest prevalence found in the caecum. Since campylobacteriosis is not considered pathogenic in poultry and is not characterized by any symptoms, when the birds reach the desired weight they are loaded onto trucks to be transported to the processing plant [6]. Modern poultry slaughterhouses are particularly efficient and present high productivity with the ability to process up to three chicken carcasses per second. Such an intensive slaughtering process can sometimes lead to contamination of chicken carcasses with Campylobacter spp. due to the spillage of intestinal contents and by contact of a carcass to the other [7]. Slaughter of chickens is a serial process, which means that cross-contamination can occur at different points in the process, where birds come into contact with each other and previously contaminated equipment [7]. Chicken carcasses that carry a high number of Campylobacter bacteria (more than $10^{3} \mathrm{cfu} / \mathrm{g}$ ) pose a significant threat to public health [8] and therefore, an important intervention for the protection of consumer health would be to reduce the number of contaminated carcasses at retail level [9].

In recent years, the emergence of antibiotic resistant strains of Campylobacter spp., which has led to failures in the treatment of campylobacteriosis in humans, has caused great concern worldwide [10]. The widespread use of antibiotics in everyday medicine and veterinary practice has been implicated in the emergence of resistant bacteria, including Campylobacter spp. In livestock, especially chickens, antibiotics have been extensively used for various purposes, such as improving yields performance, and prevention and treatment of diseases [11]. This resulted in the report of a large number of animals that were raised under subtherapeutic concentrations of antibiotics [12] and caused the creation of a pool of resistant bacteria [13].

An important aspect of the problem of antimicrobial resistance is the appearance of large numbers of Campylobacterspp. strains resistant to fluoroquinolones and specifically to ciprofloxacin. Ciprofloxacin is one of the most popular antibiotics currently used and it is considered as the antibiotic of choice for respiratory, urological, skin, arthritic or gastrointestinal infections in adults [14]. However, in many countries such as Turkey, United Kingdom, Canada and Mexico, numerous strains of Campylobacter spp. 
have been isolated either from humans or from chicken carcasses with a resistance rate of up to $90 \%$ to ciprofloxacin [15-18]. There is therefore an urgent need to control the prevalence of Campylobacter spp. in broiler carcasses and the level of antimicrobial resistance of its strains.

The aim of this study was to estimate the prevalence and antimicrobial resistance of Campylobacter spp. isolated from chicken carcasses and the environment of a poultry slaughterhouse in Greece. Furthermore, to identify the dominant Campylobacter species in the carcasses and the slaughterhouse and to determine if there are clonal relationships among the isolates in order to identify the routes of contamination and cross contamination of the carcasses.

\section{MATERIALS AND METHODS}

\section{Sample collection}

The study was conducted in a single, relatively old, but licensed and HACCP certified poultry slaughterhouse in Northern Greece, processing 6,000 birds per day. Pooled neck skins from poultry carcasses were collected in two consecutive weeks after the slaughtering process and storage in the refrigerator for two to three hours.

A sample of approximately $10 \mathrm{~g}$ from the neck skin was obtained from each carcass. The neck skin samples from three carcasses were pooled before the examination to form a $25 \mathrm{~g}$ final sample (ISO 17604:2003) [19]. A total of fifty poultry samples (coming from 150 carcasses) were examined for the presence or absence of Campylobacter spp. throughout the study (week 1: samples 1-25 and week 2: samples 26-50). The birds were originated from different farms for weeks 1 and 2. Also, 25 environmental samples, including five from the work surfaces right after the chill tank (samples 51-55), five from plastic containers filled with chicken carcasses (samples 5660), five from the handles of refrigerators (samples 61-65), five from cutting boards for preparing chicken fillets (samples 66-70) and five from the palms and fingers of the employees of the slaughterhouse (samples 71-75), were taken during the working day from the slaughterhouse. About $100 \mathrm{~cm}^{2}$ of plain surfaces, the palms and fingers of the employees and the handles of refrigerators were swabbed using a sterile cottontipped applicator moistened with Bolton broth. Then, the applicator was transferred to tubes containing $10 \mathrm{ml}$ of Bolton broth and the same area was swabbed again with a dry applicator. Three swabs were pooled as one sample. The samples were transported to the laboratory within an hour after collection in coolers with ice and were processed immediately.

\section{Isolation and Identification of Campylobacter spp.}

Campylobacter spp. were isolated using the procedures detailed in ISO 10272-1:2006. Each poultry sample $(25 \mathrm{~g})$ was mixed with $225 \mathrm{ml}$ Bolton broth in a stomacher bag, blended for 2 minutes in a Stomacher 400 laboratory blender (Seward Medical, London, 
$\mathrm{UK})$, and incubated under a microaerophilic environment $\left(44 \mathrm{~h}\right.$ at $\left.42^{\circ} \mathrm{C}\right)$. Swab samples were directly incubated into Bolton broth under the same conditions. A loopful (10 $\mu l)$ was streaked onto Karmali agar and modified cefoperazone charcoal deoxycholate agar (mCCDA). The colonies were examined after 24 and $44 \mathrm{~h}$ incubation at $42^{\circ} \mathrm{C}$. One colony was selected from each Petri dish for further analysis and was streaked to purity on Columbia blood agar $(\mathrm{CBA})\left(44 \mathrm{~h}\right.$ at $\left.42^{\circ} \mathrm{C}\right)$. The isolates were then examined for morphology, motility, catalase and oxidase activity, hippurate and indoxyl acetate hydrolysis, sensitivity to nalidixic acid and cephalothin and were stored at $-80^{\circ} \mathrm{C}$ until DNA extraction and molecular identification. All media and chemicals were obtained from Merck KGaA (Darmstadt, Germany) unless otherwise stated.

\section{Extraction of genomic DNA}

Genomic DNA was isolated from bacterial cultures according to the protocol of DNA purification from Gram Negative Bacteria by the PureLink Genomic DNA kit (Thermo Fisher Scientific) used for the molecular identification of the isolates.

\section{PCR}

Campylobacter spp. were identified by PCR amplification of $16 \mathrm{~S}$ rRNA. A fragment of 1062bp was amplified using the primer pairs as previously described [20]. C. jejuni were detected by the amplification of 344bp DNA fragment of hippuricase gene and $C$. coli by the amplification of 500bp DNA fragment of the aspartokinase gene using the primer pairs as previously described [20].

The PCR reactions were performed in $10 \mu \mathrm{l}$ final volume. Each reaction consisted of 1X PCR buffer (BioRon, SuperHotTaq DNA polymerase, Life Science), 3mM MgCl, $250 \mu \mathrm{M}$ of each dNTP, $300 \mathrm{nM}$ of each primer, $1 \mathrm{U}$ of SuperHot polymerase (BioRon, Life Science) and 200ng genomic DNA from the bacterial strains. The PCR started with an initial denaturation step at $94^{\circ} \mathrm{C}$ for $2 \mathrm{~min}$, followed by 30 cycles of denaturation at $94^{\circ} \mathrm{C}$ for $10 \mathrm{~s}$, annealing at $60^{\circ} \mathrm{C}$ for $25 \mathrm{~s}$ and extension at $72^{\circ} \mathrm{C}$ for $1 \mathrm{~min}$ and with a final extension at $72^{\circ} \mathrm{C}$ for $7 \mathrm{~min}$. The PCR amplified products were electrophorized in $1.5 \%$ agarose gels and were visualized under UV illumination by the TEX-20M after staining with ethidium bromide (Life Technologies, GibcoBRL system).

\section{Antimicrobial susceptibility testing}

Susceptibility to a panel of six antimicrobials (gentamicin, streptomycin, tetracycline, ciprofloxacin, nalidixic acid and erythromycin) was determined by a breakpoint method in Mueller-Hinton agar (Merck, Damstand, Germany) supplemented with 5\% defibrinated horse blood (Merck, Damstand, Germany) as described in a previous study [21] with incubation in an microaerobic environment at $41^{\circ} \mathrm{C}$ for $24 \mathrm{~h}$. The final plate concentrations ( $\mathrm{mg} / \mathrm{L})$ were: gentamicin $(\mathrm{G})(2)$, streptomycin $(\mathrm{S})$ (8 and 128); tetracycline (T) (2 and 128); ciprofloxacin (Cp) (1); nalidixic acid ( $\mathrm{Nx}$ ) (32); erythromycin (Er) (8). Multidrug resistance was defined as previously proposed in another study [22]. Staphylococcus aureus ATCC 25923 was used as the reference strain. 


\section{PFGE typing}

Pulsed Field Gel Electrophoresis (PFGE) was performed using SmaI-digested (TaKaRa, Kyoto, Japan) fragments of bacterial chromosomal DNA according to PulseNet protocol [23]. Restriction fragments of DNA were separated by PFGE using 1\% Seakem Gold agarose gels (FMC BioProducts, Rockland, MD, USA) in 0.5X Trisborate-EDTA buffer with CHEF-DR III (Bio-Rad, Hercules, CA, USA). Salmonella serotype Branderup strain H9812 digested with 40 units XbaI (TaKaRa, Kyoto, Japan) was used as the size standard, as recommended by PulseNet. Electrophoresis conditions were $14^{\circ} \mathrm{C}$ for $19 \mathrm{~h}$, with pulse time ranging from 6.8 to $35.4 \mathrm{~s}$ at an angle of $120^{\circ}$. Gels were stained with a solution of ethidium bromide and photographed. A database containing all the PFGE patterns were created by using Bionumerics software (version 6.6 Applied Maths, Sint-Martens-Latem, Belgium), where band patterns over the multiple gels were normalized and compared. Clustering was performed by using the Dice similarity coefficient and the unweighted pair group method with arithmetic means (UPGMA), with $1.5 \%$ of tolerance and optimization. Patterns that differed by more than one fragment were considered belonging to the distinct PFGE-type designated as CC.001, CC.002 etc.

\section{RESULTS}

\section{Prevalence and identification of Campylobacter spp.}

Forty-nine of fifty poultry pooled samples (98\%) were positive for Campylobacter spp. The environment of the slaughterhouse was also contaminated with Campylobacter spp. All samples taken from the inner side of the hands of the employees of the slaughterhouse, the plastic containers, and the cutting boards were contaminated with Campylobacter spp. For the other two sampling points, only one sample taken from the work surfaces right after the chill tank and another one from the handles of refrigerators were contaminated. The detailed results concerning the prevalence of Campylobacter spp. on the carcasses and the environment of the slaughterhouse are illustrated in Table 1.

Table 1. Presence of Campylobacterspp. in the carcasses and the environment of a slaughterhouse, Greece, 2016

\begin{tabular}{lccc}
\hline & Positive samples & Total samples & Contamination \% \\
\hline Carcasses & 49 & 50 & 98 \\
Work surfaces after chill tank & 1 & 5 & 20 \\
Containers with chickens & 5 & 5 & 100 \\
Refrigerator door handles & 1 & 5 & 20 \\
Cutting boards & 5 & 5 & 100 \\
Palms and fingers of employees & 5 & 5 & 100 \\
\hline
\end{tabular}

Fifty-nine isolates were identified as Campylobacter coli, four as Campylobacter jejuni and three were found to belong to another species and were characterized as Campylobacter spp. The analytical results are shown in Table 2. 
Table 2. Molecular identification of Campylobacter spp.

\begin{tabular}{|c|c|c|c|c|}
\hline \multirow{2}{*}{ Isolates } & \multicolumn{3}{|c|}{ Primers } & \multirow{2}{*}{ Species } \\
\hline & $16 \mathrm{~s}$ & ASP & HIP & \\
\hline $\begin{array}{l}1,2,3,4,5,6,7,8,9,10,11,12,13,14,15,16,17, \\
19,20,21,22,24,25,26,27,28,29,30,31,32,33, \\
34,35,36,39,40,41,42,43,44,45,46,47,48,49, \\
50,56,57,58,59,60,62,66,69,70,72,73,74,75\end{array}$ & + & + & - & C. $\operatorname{coli}(59)$ \\
\hline $23,67,68,71$ & + & - & + & C. jejuni (4) \\
\hline $37,38,51$ & + & - & - & Campylobacter spp. (3) \\
\hline
\end{tabular}

+: PCR amplification, -: absence of PCR amplification

\section{Antimicrobial susceptibility}

The antimicrobial resistance of the sixty-six isolates (C. coli, C. jejuni and Campylobacter spp.) and their antimicrobial resistance profiles are illustrated in Table 3 and 4, respectively. Thirty-seven isolates were sensitive to all antimicrobials tested $(56.1 \%)$ and twenty-nine were resistant to at least two of the antimicrobials (43.9\%). Five distinct resistance profiles were observed among the twenty-nine resistant isolates (Table 4). Thirty-two of fifty-nine $C$. coli isolates, all four C. jejuni isolates (isolates 23, $67,68,71$ ) and one (isolate 51) of the three unidentified Campylobacter isolates were found sensitive to all antimicrobials tested (Table 1). As far as the origin of the isolates is concerned, twenty-seven of the forty-nine poultry isolates were found resistant to at least two of the antimicrobials used, whereas only two (isolates 57 and 58) of the sixteen environmental isolates have showed resistance (Table 3).

Table 3. Antimicrobial resistance of the poultry and environmental Campylobacter spp. isolates against 6 antimicrobials

\begin{tabular}{|c|c|c|c|c|c|c|}
\hline \multicolumn{7}{|c|}{ Antimicrobial resistance of the poultry and environmental Campylobacter spp. isolates } \\
\hline Isolates & CIPRO 1 & ERY 8 & GENT4 & NAL 32 & STR 8 & TET 2 \\
\hline $\begin{array}{c}1,2,3,4,5,6,7,8,9,10,11,12,13, \\
14,15,16,17,23,24,25,26,27,51, \\
56,59,60,62,66,67,68,69,70,71, \\
72,73,74,75\end{array}$ & $\mathrm{~S}$ & $\mathrm{~S}$ & $\mathrm{~S}$ & $\mathrm{~S}$ & S & S \\
\hline 19,33 & $\mathrm{R}$ & $\mathrm{R}$ & $\mathrm{R}$ & $\mathrm{R}$ & $\mathrm{R}$ & $\mathrm{R}$ \\
\hline $\begin{array}{c}20,21,22,28,29,30,31,34,46,47, \\
48\end{array}$ & $\mathrm{R}$ & $\mathrm{R}$ & $\mathrm{S}$ & $\mathrm{R}$ & $\mathrm{R}$ & $\mathrm{R}$ \\
\hline $32,35,36,43,44,45,38,39,40,41$ & $\mathrm{R}$ & $\mathrm{R}$ & S & $\mathrm{R}$ & $\mathrm{R}$ & S \\
\hline $37,42,49,57,58$ & S & $\mathrm{R}$ & S & $\mathrm{R}$ & $\mathrm{R}$ & $\mathrm{R}$ \\
\hline 50 & $\mathrm{~S}$ & $\mathrm{~S}$ & $\mathrm{~S}$ & $\mathrm{R}$ & $\mathrm{R}$ & S \\
\hline Resistant isolates & 23 & 28 & 2 & 29 & 29 & 18 \\
\hline Total isolates & 66 & 66 & 66 & 66 & 66 & 66 \\
\hline Resistance \% & 34.85 & 42.42 & 3.03 & 43.94 & 43.94 & 27.27 \\
\hline
\end{tabular}


Table 4. Antimicrobial resistance profiles of the Campylobacter spp. isolates

\begin{tabular}{lcc}
\hline \multirow{2}{*}{ Resistance profiles } & \multicolumn{2}{c}{ Campylobacter spp. isolates } \\
\cline { 2 - 3 } & Number & $\%$ \\
\hline Susceptible & 37 & 56.06 \\
$\mathrm{Nx}+\mathrm{S}$ & 1 & 1.51 \\
$\mathrm{E} r+\mathrm{Nx}+\mathrm{S}+\mathrm{Te}$ & 5 & 7.57 \\
$\mathrm{Cip}+\mathrm{Er}+\mathrm{Nx}+\mathrm{S}$ & 10 & 15.15 \\
$\mathrm{Cip}+\mathrm{Er}+\mathrm{Nx}+\mathrm{S}+\mathrm{Te}$ & 11 & 16.67 \\
$\mathrm{Cip}+\mathrm{Er}+\mathrm{Gm}+\mathrm{Nx}+\mathrm{S}+\mathrm{Te}$ & 2 & 3.03 \\
\hline
\end{tabular}

Nalidixic acid (Nx), Streptomycin (S), Erythromycin (Er), Tetracycline (Te), Ciprofloxacin (Cip), Gentamicin (Gm)

\section{PFGE typing}

Among fifty-nine C. coli isolates, fifty-three were typeable by PFGE (typeability 90\%), while six isolates were excluded because their PFGE patterns were not distinguishable after multiple attempts. We also excluded from our analysis the C. jejuni and the Campylobacter spp. isolates because of their low numbers. Results from the PFGE
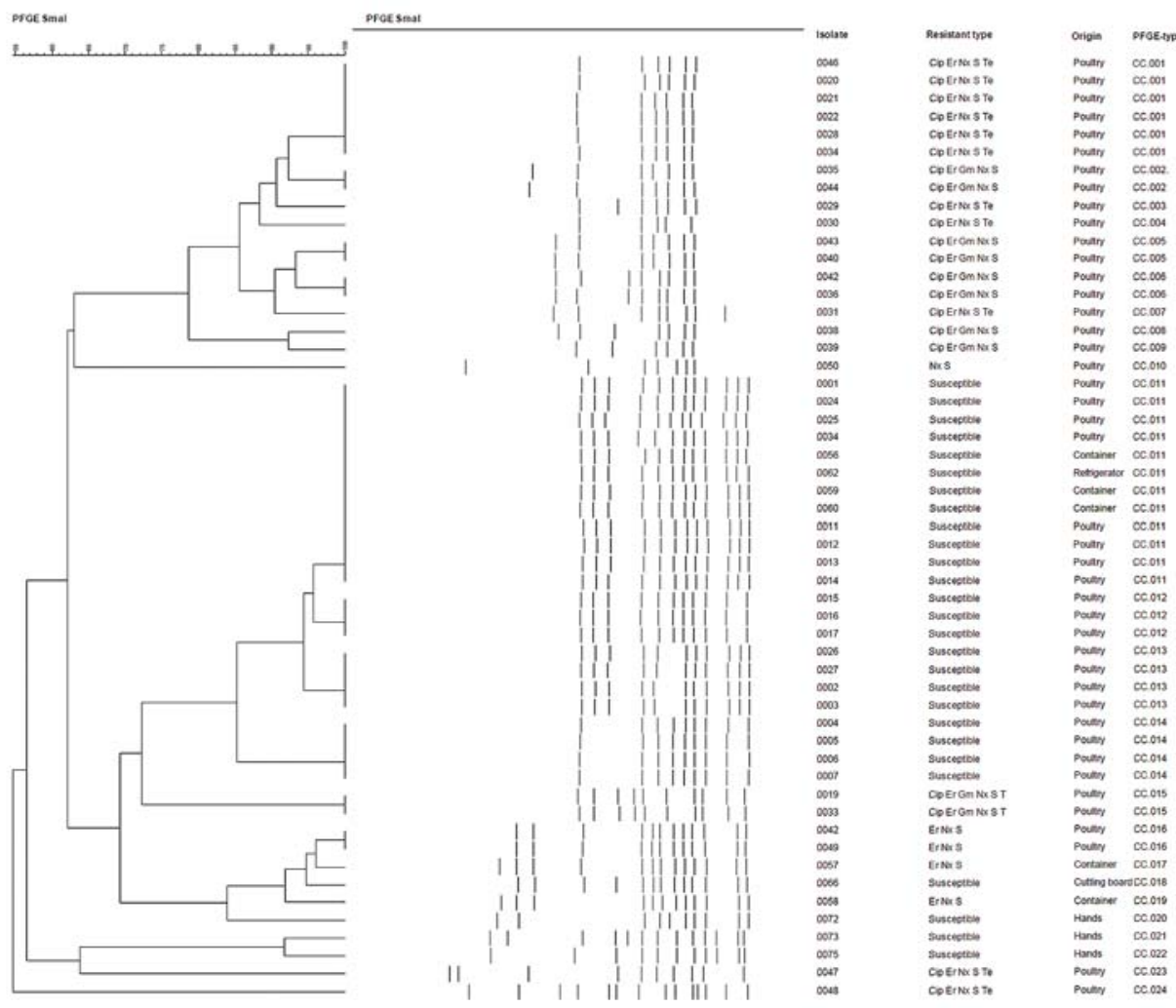

Figure 1. Dendrogram of the 24 SmaI PFGE types of 53 Campylobacter coli isolates and corresponding R-types examined in this study 
analysis of the $C$. coli strains isolated from chicken carcasses and the environment of the slaughterhouse are depicted in the dendrogram of Figure 1. Overall, twenty-four different PFGE types were observed among the fifty-three isolates with fourteen of them being isolated once, while five PFGE-types were represented by two isolates. The remaining twenty-nine isolates were represented by five PFGE-types consisting of three to twelve isolates. The predominant PFGE type was CC.0011 consisting of twelve (12) isolates, followed by CC.001 consisting of six (6) isolates, CC.013 and CC.014 each one consisting of four (4) isolates and CC.012 consisting of three (3) isolates. The PFGE-type (CC.011) encompassed mostly isolates from chicken carcasses $(\mathrm{N}=8)$, from plastic containers $(\mathrm{N}=3)$ and door handles $(\mathrm{N}=1)$, while PFGE types CC.001, CC.012, CC.013 and CC.014 originated only from chicken isolates.

Regarding the relationship of the PFGE types and corresponding resistance profiles we observed that all the strains of each PFGE-type shared the same antimicrobial resistance profile.

\section{DISCUSSION}

This study reports the prevalence, the antimicrobial resistance and the genetic diversity of Campylobacter strains isolated from poultry carcasses, the environment and processing equipment of a slaughterhouse in Greece. The prevalence of Campylobacter on chicken carcasses was found to be very high with $98 \%$ of the carcasses being contaminated. These results, although higher, are in accordance with the recent EU summary report [1], which shows that the overall occurrence of Campylobacter in fresh broiler meat in the EU in 2017 was $37.4 \%$. In the same report, a significant variation of Campylobacter contamination prevalence is reported, since the prevalence of Campylobacter contamination in chicken carcasses at the slaughterhouse level varies among Member States. Similar studies from other European countries demonstrate a variation in prevalence of contamination between different countries like Italy $(5.7 \%$ and $20.7 \%$ ), France (64.7\%), UK (65\%), Belgium (51.9\%), and Estonia (35\%) [2429]. In a study reviewing seventy-three investigations of retail poultry meat all over the world, the levels of contamination by Campylobacter spp. were found high and extremely variable, with a total average of $58 \%$ [30]. As stated in a recent study [31], the variable prevalence of Campylobacter on chicken carcasses can be attributed to the type and number of samples, different methods of collection of samples, transport conditions, laboratory methods and different sanitary conditions on poultry farms and slaughterhouses.

Relating to previous investigations conducted in Greece, our findings have shown a high overall prevalence of Campylobacter contamination of chicken carcasses. Petridou and Zdragas suggested a prevalence of $73.3 \%$ of Campylobacter spp. in poultry meat in 2009 [32], while Marinou et al. (2012) reported the absence of Campylobacter strains in caecal samples from chicken carcasses [33]. In the most recent study conducted in Greece [34], Campylobacter spp. were isolated in $29.4 \%$ of the samples from free-range broilers and in $28.7 \%$ of the samples from conventional broilers. 
As previously mentioned, the environment and processing equipment of the slaughterhouse that was used for this study was found to be contaminated with Campylobacter spp. Some of the surfaces that are regularly exposed to poultry carcasses like the plastic containers, the cutting boards and the inner side of the hands of the employees, were found contaminated and all the samples taken were positive. This finding can reflect the high prevalence of Campylobacter spp. on poultry carcasses and could explain the higher percentage of contamination comparing this study with previous similar studies. A flock that is contaminated with Campylobacter spp. can lead to the contamination of surfaces of the slaughterhouse; this also means that poultry meat from broiler flocks negative for Campylobacter spp. could also be contaminated if the previous slaughtered flock was positive and the bacteria remain on the surfaces of the equipment in the slaughterhouse [35]. However, Campylobacter spp. cannot grow and survive well in the environment for long periods [36] and is sensitive to the disinfectants that are generally used in poultry slaughterhouses [37]. This means that either there was a failure in the cleaning procedures taking place at the slaughterhouse, or that some of the flocks slaughtered within the day were contaminated and this resulted to a cross-contamination of the carcasses of the following flocks.

The distribution of the bacteria isolated to the species level revealed that the most commonly isolated Campylobacter species was C. coli $(89.4 \%)$, followed by C. jejuni (6\%) and unidentified Campylobacter spp. (4.6\%). This observation comes in contradiction with the findings of many researchers who report that $C$. jejuni presents a higher prevalence in chicken carcasses in relation to C. coli. C. jejuni was found to be the predominant Campylobacter species in several studies in Greece [32, 34], France [24], Estonia [28], and Brazil [31,38]. However, there are some other recent studies where C. coli and C. jejuni prevalence is similar [39] or even the isolation proportion of $C$. coli is higher [40]. Other studies from Greece [33], and Italy [26, 27] also report high prevalence for C. coli, being as high as $87.5 \%, 42.9 \%$ and $63 \%$, respectively. Suzuki and Yamamoto (2009) reported that in most countries, C. jejuni is the dominant species isolated, although the ratio of $C$. coli to $C$. jejuni varied substantially between the countries. A recent work in Italy [41] has pointed out that the isolation proportions of $C$. coli and C. jejuni may vary, depending on the sampling point. In particular, they report that $C$. jejuni is significantly higher than $C$. coli on the farm, during slaughter the percentages are balanced and $C$. coli levels are higher than those of $C$. jejuni after immersion of the carcasses into the chill tank. Considering that in the present study sampling was performed after the immersion of the carcasses in the chill tank and their storage in the refrigerator, this can explain the higher proportion of C. coli than C. jejuni isolates.

Regarding the antimicrobial resistance, there was a relatively lower resistance to the six antimicrobials used in this study compared with previous studies. A recent study from Greece [34] reported that less than 20\% of the Campylobacter isolates tested were found susceptible to all antimicrobials used in the study, while $56.1 \%$ of the isolates of this study were susceptible. Our resistance rates for ciprofloxacin $(34.8 \%)$, erythromycin 
$(42.4 \%)$ and tetracycline $(27.3 \%)$ were significantly lower than the previous study $(51 \%$, $76 \%$ and $71 \%$, respectively) and only for gentamicin the results were comparable $(3 \%$ and $0 \%$ ). Nalidixic acid and streptomycin resistance rates were found to be higher than the other antibiotics used in this study, with $43.94 \%$ of the isolates being resistant to both antibiotics. These antibiotics were not tested in the previous study [34] and amikacin was used instead, representing aminoglycosides, showing a resistance rate of $15 \%$. In a previous study from Greece [33], all Campylobacter isolates were found susceptible to ciprofloxacin and amoxicillin-clavulanic acid, while the resistance rates were low for nalidixic acid (14.28\%) and gentamicin (14.3\%) and high for erythromycin $(92.8 \%)$ and ampicillin (92.8\%). The Campylobacter isolates of this previous study originated from poultry feces at farm level, thus not providing the information of the potential Campylobacter isolates from carcasses after slaughter. An important finding of our study, which was confirmed by this previous study, was that $C$. coli isolates tend to be more resistant than $C$. jejuni isolates. In our study, all $C$. jejuni isolates were susceptible to the antibiotics used. Although the number of $C$. jejuni isolates in both studies (ours and Marinou et al., 2012) was relatively low and we cannot draw a certain conclusion, this finding has also been reported by other researchers in the past [42]. However, there are other researchers who supported that $C$. jejuni showed higher resistance compared to $C$. coli, which was statistically significant for ciprofloxacin, gentamycin and norfloxacin [27].

In other Mediterranean countries like France and Italy, the resistance rates for Campylobacter isolates were similar or higher. A study from France [24] reports that $62 \%$ of the isolates were resistant to at least one antimicrobial agent tested, with resistance to tetracycline being the most common $(53.6 \%)$, followed by ciprofloxacin $(32.9 \%)$ and nalidixic acid (32.0\%). In the same study, $22.7 \%$ of the isolates demonstrated simultaneous resistance to ciprofloxacin, nalidixic acid and tetracycline, a percentage that is similar to the one in our study for the same antibiotics $(19.7 \%)$. A study from Italy [27] also reported resistance to tetracycline being the most common $(90.7 \%)$ followed by nalidixic acid (79.1\%), erythromycin (72.1\%), ciprofloxacin $(48.5 \%)$ and gentamycin $(27.9 \%)$. A quarter of the isolates $(25.6 \%)$ were found resistant to ciprofloxacin and erythromycin, $13.9 \%$ were resistant to all the quinolones tested (ciprofloxacin, norfloxacin, pefloxacin and nalidixic acid) and 9.3\% were resistant to all quinolones and erythromycin. Another study, from Estonia [28], stated that 63.3\% of the isolates were resistant to at least one antibiotic, with the fluoroquinolone resistance rate being $41.8 \%$ and $8.2 \%$ of the isolates being resistant to ciprofloxacin, nalidixic acid and tetracycline simultaneously. Finally, in Brazil, the highest resistance rates for fluoroquinolones were reported, with $100 \%$ of the isolates being resistant to ciprofloxacin and enrofloxacin [31].

A noteworthy genomic variability among the fifty-three C. coli isolates was observed in this study; this was demonstrated by the large number (twenty-four) of distinct PFGE patterns indicating multiple sources of contamination. Diversity in unrelated epidemiological strains has also been observed by several authors $[43,44]$ suggesting 
that there is a diverse population of $C$. coli circulating in the poultry meat industry. We observed that for twelve isolates sharing the same PFGE type, eight of them were from chicken carcasses, three from the plastic container and one from door handles. This indicates cross contamination through the slaughter procedure. Other studies suggest that the source of contamination is mainly the chicken flock, and that cross contamination in the slaughter house is also taking place [45]. Furthermore, Sasaki et al. suggest that cross contamination can also happen between birds slaughtered on different days [46]. This was confirmed in our study since chicken and environmental isolates coming from different sampling dates were found to belong to the same PFGE type. Therefore, there was either a cross contamination between birds slaughtered on different days due to cleaning failure, or the sources of contamination of the different birds were the same, causing the infection of the birds by the same Campylobacter strains.

We also observed that all the isolates belonging to a certain PFGE type shared common antimicrobial resistance profiles, with no exceptions. Even isolates that were taken on different sampling days and belonged to the same PFGE type were found to have the same antimicrobial resistance profile. This strengthens our observation for clonal circulation during the slaughter procedure.

\section{CONCLUSION}

This study performs evidence of Campylobacter cross-contamination among broiler carcasses in a slaughterhouse. The prevalence of Campylobacter in chicken carcasses was observed to be very high and that was the case for some surfaces of the slaughterhouse that are regularly exposed to the chicken carcasses. An increased emphasis on cleaning combined with improved personal and general hygiene in the slaughterhouse could reduce the cross-contamination of the birds and potentially lower the percentages of contaminated poultry, improving the safety of chicken products. With respect to the antibiotic resistance observed, there was a relatively lower resistance to the antimicrobials used in this study compared with previous studies; this could actually reflect the outcomes of the efforts of the scientific community and industry over the last few years for a more prudent use of antibiotics in the food-producing animals. However, antimicrobial resistance remains a wide spread threat emphasizing the need for continuous surveillance and monitoring of the use of antimicrobial agents in husbandry.

\section{Acknowledgements}

The authors would like to thank the action AgroETAK and the Operational Programme "Development of Human Resources 2007-2013" for funding this research and the Hellenic Agricultural Organization "DEMETER" for its implementation. 


\section{Authors' contributions}

SI conceived the study, carried out the microbiological analysis, participated in the PCR, PFGE and antimicrobial susceptibility testing and drafted the manuscript. PT carried out the PFGE and antimicrobial susceptibility testing and helped to draft the manuscript. BE and EL carried out the PCR and helped to draft the manuscript. SG and ZA participated in the design of the study and helped to draft the manuscript. All authors read and approved the final manuscript.

\section{Declaration of conflicting interests}

The author(s) declared no potential conflicts of interest with respect to the research, authorship, and/or publication of this article.

\section{REFERENCES}

1. European Food Safety Authority EFSA, European Centre for Disease Control and Prevention ECDC: The European Union summary report on trends and sources of zoonoses, zoonotic agents and food-borne outbreaks in 2015. EFSA Journal 2016, 14(12):e04634-n/a.

2. Man SM: The clinical importance of emerging Campylobacter species. Nat Rev Gastroenterol Hepatol 2011, 8(12):669-685.

3. Hughes RA, Cornblath DR: Guillain-Barre syndrome. Lancet 2005, 366(9497):1653-1666.

4. Collett SR: Nutrition and wet litter problems in poultry. Animal Feed Science and Technology 2012, 173(1):65-75.

5. Torok VA, Hughes RJ, Ophel-Keller K, Ali M, Macalpine R: Influence of different litter materials on cecal microbiota colonization in broiler chickens. Poult Sci 2009, 88(12):24742481.

6. Humphrey S, Chaloner G, Kemmett K, Davidson N, Williams N, Kipar A, Humphrey T, Wigley P: \&lt;span class=\&quot;named-content genus-species\&quot; id=\&quot;namedcontent-1\&quot;\&gt;Campylobacter jejuni\&lt;/span\&gt; Is Not Merely a Commensal in Commercial Broiler Chickens and Affects Bird Welfare. mBio 2014, 5(4).

7. Facciolà A, Riso R, Avventuroso E, Visalli G, Delia SA, Laganà P: Campylobacter: from microbiology to prevention. Journal of preventive medicine and hygiene 2017, 58(2):E79-E92.

8. Lindqvist R, Lindblad M: Quantitative risk assessment of thermophilic Campylobacter spp. and cross-contamination during handling of raw broiler chickens evaluating strategies at the producer level to reduce human campylobacteriosis in Sweden. Int J Food Microbiol 2008, 121(1):41-52.

9. Rosenquist H, Boysen L, Galliano C, Nordentoft S, Ethelberg S, Borck B: Danish strategies to control Campylobacter in broilers and broiler meat: facts and effects. Epidemiol Infect 2009, 137(12):1742-1750.

10. Dingle KE, Clarke L, Bowler IC: Ciprofloxacin resistance among human Campylobacter isolates 1991-2004: an update. J Antimicrob Chemother 2005, 56(2):435-437.

11. Landers TF, Cohen B, Wittum TE, Larson EL: A Review of Antibiotic Use in Food Animals: Perspective, Policy, and Potential. Public Health Reports 2012, 127(1):4-22. 
12. Franco DA, Webb J, Taylor CE: Antibiotic and Sulfonamide Residues in Meat: Implications for Human Health. Journal of Food Protection 1990, 53(2):178-185.

13. Smith KE, Besser JM, Hedberg CW, Leano FT, Bender JB, Wicklund JH, Johnson BP, Moore KA, Osterholm MT: Quinolone-resistant Campylobacter jejuni infections in Minnesota, 1992-1998. Investigation Team. N Engl J Med 1999, 340(20):1525-1532.

14. Dryden MS, Gabb RJ, Wright SK: Empirical treatment of severe acute community-acquired gastroenteritis with ciprofloxacin. Clin Infect Dis 1996, 22(6):1019-1025.

15. Abay S, Kayman T, Otlu B, Hizlisoy H, Aydin F, Ertas N: Genetic diversity and antibiotic resistance profiles of Campylobacter jejuni isolates from poultry and humans in Turkey. Int J Food Microbiol 2014, 178:29-38.

16. Agunos A, Leger D, Avery BP, Parmley EJ, Deckert A, Carson CA, Dutil L: Ciprofloxacinresistant Campylobacter spp. in retail chicken, western Canada. Emerg Infect Dis 2013, 19(7):1121-1124.

17. Strachan NJ, Forbes KJ: The growing UK epidemic of human campylobacteriosis. Lancet 2010, 376(9742):665-667.

18. Zaidi MB, McDermott PF, Campos FD, Chim R, Leon M, Vazquez G, Figueroa G, Lopez E, Contreras J, Estrada-Garcia T: Antimicrobial-resistant Campylobacter in the food chain in Mexico. Foodborne Pathog Dis 2012, 9(9):841-847.

19. International Organization for Standardization: Microbiology of food and animal feeding stuffs_carcass sampling for microbiological analysis ISO 17604:2003. In. Geneva: International Organization for Standardization; 2009.

20. Persson S, Olsen KE: Multiplex PCR for identification of Campylobacter coli and Campylobacter jejuni from pure cultures and directly on stool samples. J Med Microbiol 2005, 54(Pt 11):1043-1047.

21. Clinical and Laboratory Standards Institute CLSI: Methods for Antimicrobial Susceptibility Testing of Anaerobic Bacteria; Approved Standard 8th edition CLSI document M11-A8. In., edn. Wayne, PA: CLSI; 2012.

22. Magiorakos AP, Srinivasan A, Carey RB, Carmeli Y, Falagas ME, Giske CG, Harbarth S, Hindler JF, Kahlmeter G, Olsson-Liljequist B et al: Multidrug-resistant, extensively drugresistant and pandrug-resistant bacteria: an international expert proposal for interim standard definitions for acquired resistance. Clinical Microbiology and Infection 2012, 18(3):268-281.

23. Ribot EM, Fitzgerald C, Kubota K, Swaminathan B, Barrett TJ: Rapid pulsed-field gel electrophoresis protocol for subtyping of Campylobacter jejuni. J Clin Microbiol 2001, 39(5):1889-1894.

24. Guyard-Nicodeme M, Rivoal K, Houard E, Rose V, Quesne S, Mourand G, Rouxel S, Kempf I, Guillier L, Gauchard F et al: Prevalence and characterization of Campylobacter jejuni from chicken meat sold in French retail outlets. Int J Food Microbiol 2015, 203:8-14.

25. Habib I, Berkvens D, De Zutter L, Dierick K, Van Huffel X, Speybroeck N, Geeraerd AH, Uyttendaele M: Campylobacter contamination in broiler carcasses and correlation with slaughterhouses operational hygiene inspection. Food Microbiol 2012, 29(1):105-112.

26. Mezher Z, Saccares S, Marcianò R, De Santis P, Rodas EMF, De Angelis V, Condoleo R: Occurrence of Campylobacter spp. in Poultry Meat at Retail and Processing Plants Levels in Central Italy. Italian Journal of Food Safety 2016, 5(1):5495.

27. Nobile CGA, Costantino R, Bianco A, Pileggi C, Pavia M: Prevalence and pattern of antibiotic resistance of Campylobacter spp. in poultry meat in Southern Italy. Food Control 2013, 32(2):715-718. 
28. Meremäe K, Mäesaar M, Kramarenko T, Häkkinen L, Roasto M: The prevalence, counts and antimicrobial suspectibility of thermophilic Campylobacter spp. in fresh chicken meat at Estonian retail level. Agraarteadus 2015.

29. Anonymous: A UK survey of Campylobacter and Salmonella contamination of fresh chicken at retail sale. Food Survey Information sheet 04/09. In. Edited by Agency FS; 2009.

30. Suzuki H, Yamamoto S: Campylobacter contamination in retail poultry meats and by-products in the world: a literature survey. J Vet Med Sci 2009, 71(3):255-261.

31. Panzenhagen PHN, Aguiar WS, da Silva Frasão B, de Almeida Pereira VL, da Costa Abreu DL, dos Prazeres Rodrigues D, do Nascimento ER, de Aquino MHC: Prevalence and fluoroquinolones resistance of Campylobacter and Salmonella isolates from poultry carcasses in Rio de Janeiro, Brazil. Food Control 2016, 61:243-247.

32. Petridou E, Zdragas A: Investigation upon the presence of Campylobacter spp. in poultry meat and their antimicrobial resistance in Northern Greece. . In: 16th World veterinary poultry association Congress: 2009; Morocco; 2009: p419.

33. Marinou I, Bersimis S, Ioannidis A, Nicolaou C, Mitroussia-Ziouva A, Legakis NJ, Chatzipanagiotou S: Identification and Antimicrobial Resistance of Campylobacter Species Isolated from Animal Sources. Frontiers in Microbiology 2012, 3:58.

34. Economou V, Zisides N, Gousia P, Petsios S, Sakkas H, Soultos N, Papadopoulou C: Prevalence and antimicrobial profile of Campylobacter isolates from free-range and conventional farming chicken meat during a 6-year survey. Food Control 2015, 56:161-168.

35. Allen VM, Bull SA, Corry JE, Domingue G, Jorgensen F, Frost JA, Whyte R, Gonzalez A, Elviss N, Humphrey TJ: Campylobacter spp. contamination of chicken carcasses during processing in relation to flock colonisation. Int J Food Microbiol 2007, 113(1):54-61.

36. Alter T, Scherer K: Stress response of Campylobacter spp. and its role in food processing. J Vet Med B Infect Dis Vet Public Health 2006, 53(8):351-357.

37. Peyrat MB, Soumet C, Maris P, Sanders P: Phenotypes and genotypes of campylobacter strains isolated after cleaning and disinfection in poultry slaughterhouses. Vet Microbiol 2008, 128(3-4):313-326.

38. Silva DT, Tejada TS, Blum-Menezes D, Dias PA, Timm CD: Campylobacter species isolated from poultry and humans, and their analysis using PFGE in southern Brazil. Int J Food Microbiol 2016, 217:189-194.

39. Zhu J, Yao B, Song X, Wang Y, Cui S, Xu H, Yang B, Huang J, Liu G, Yang X et al: Prevalence and quantification of Campylobacter contamination on raw chicken carcasses for retail sale in China. Food Control 2017, 75:196-202.

40. Khoshbakht R, Tabatabaei M, Hosseinzadeh S, Shirzad Aski H, Seifi S: Genetic Characterization of Campylobacter Jejuni and C. coli Isolated From Broilers Using flaA PCRRestriction Fragment Length Polymorphism Method in Shiraz, Southern Iran. Jundishapur J Microbiol 2015, 8(5):e18573.

41. Marotta F, Garofolo G, Di Donato G, Aprea G, Platone I, Cianciavicchia S, Alessiani A, Di Giannatale E: Population Diversity of Campylobacter jejuni in Poultry and Its Dynamic of Contamination in Chicken Meat. BioMed Research International 2015, 2015:10.

42. Gallay A, Prouzet-Mauléon V, Kempf I, Lehours P, Labadi L, Camou C, Denis M, de Valk H, Desenclos J-C, Mégraud F: Campylobacter Antimicrobial Drug Resistance among Humans, Broiler Chickens, and Pigs, France. Emerging Infectious Diseases 2007, 13(2):259-266.

43. Vidal AB, Colles FM, Rodgers JD, McCarthy ND, Davies RH, Maiden MCJ, CliftonHadley FA: Genetic Diversity of Campylobacter jejuni and Campylobacter coli Isolates from 
Conventional Broiler Flocks and the Impacts of Sampling Strategy and Laboratory Method. Applied and Environmental Microbiology 2016, 82(8):2347-2355.

44. Pergola S, Franciosini MP, Comitini F, Ciani M, De Luca S, Bellucci S, Menchetti L, Casagrande Proietti P: Genetic diversity and antimicrobial resistance profiles of Campylobacter coli and Campylobacter jejuni isolated from broiler chicken in farms and at time of slaughter in central Italy. J Appl Microbiol 2017, 122(5):1348-1356.

45. Normand V, Boulianne M, Quessy S: Evidence of cross-contamination by Campylobacter spp. of broiler carcasses using genetic characterization of isolates. Canadian Journal of Veterinary Research 2008, 72(5):396-402.

46. Sasaki Y, Maruyama N, Zou B, Haruna M, Kusukawa M, Murakami M, Asai T, Tsujiyama Y, Yamada Y: Campylobacter cross-contamination of chicken products at an abattoir. Zoonoses Public Health 2013, 60(2):134-140.

\section{PREVALENCIJA, ANTIMIKROBNA REZISTENCIJA I MOLEKULARNA TIPIZACIJA TERMOFILNIH Campylobacter spp U KLANICI ŽIVINE U GRČKOJ}

SAKARIDIS Ioannis, PAPADOPOULOS Theofilos, BOUKOUVALA Evridiki, EKATERINIADOU Loukia, SAMOURIS Georgios, ZDRAGAS Antonios

Campylobacter spp. su jedan od vodećih uzroka alimentarnih infekcija. Živina predstavlja glavni rezervoar i izvor ovih mikroorganizama za ljude. Cilj ove studije je bio da se proceni prevalencija i antimikrobna rezistencija Campylobacter spp. izolovanih sa trupova živine, okruženja, i klanične opreme u okviru jedne klanice u Grčkoj, odredi dominantna Campylobacter spp. i ustanovi da li postoji klonska veza između izolata. Pedeset uzoraka živine i dodatnih 25 uzoraka iz okruženja su ispitana putem kulture mikroorganizama i pomoću PCR. Četrdeset i pet od pedeset uzoraka živine (98\%) je bilo pozitivno na Campylobacter spp. Uočena je i značajna kontaminacija okruženja. Trideset i sedam izolata je bilo osetljivo na sve testirane antimikrobne preparate (56,1\%), a 29 izolata je bilo rezistentzno na najmenje dva testirana antimikrobna preparata (43,9\%). Među 53 ispitana izolata bilo je 24 različita PFGE tipa, od njih 14 je izolovano samo jedan put, dok je 5 PFGE -tipova bilo predstavljeno sa dva izolata. Preostalih 29 izolata je bilo predstavljeno putemn pet PFGE- tipova koji su se sastojali od tri do 12 izolata. Što se tiče odnosa PFGE-tipova i odgovarajućeg profila rezistencije, svi sojevi svakog PFGE-tipa su delili isti profil rezistencije. Ova studija predstavlja dokaz unakrsne Campylobacter spp. kontaminacije unutar jedne klanice u Grčkoj. 